Original Research

\title{
Social Care in Improving Self-Concept of Leprosy Patients
}

\author{
Nur Hamim1, Mariani Mariani' ${ }^{1}$, and Sismulyanto Sismulyanto² \\ ${ }^{1}$ Sekolah Tinggi Ilmu Kesehatan Hafshawaty Zainul Hasan, Probolinggo, East Java, Indonesia \\ ${ }^{2}$ Sekolah Tinggi Ilmu Kesehatan Qomarul Huda Mataram, West Nusa Tenggara, Indonesia
}

\begin{abstract}
Introduction: Many infectious diseases occur in developing countries with low socioeconomic conditions. One such is leprosy. Leprosy is common in developing countries as a result of the country's limited ability to provide adequate services, including among some health workers. Such health workers are lacking knowledge and understanding of the false beliefs of leprosy and its resulting disabilities. The purpose of this research is to formulate a social care model in improving self-concept of leprosy patients in Probolinggo District.
\end{abstract}

Methods: This research used explanatory research survey method with a crosssectional approach. The sample was 56 respondents. The variables were family support, social care and self-concept. The data were collected using a questionnaire modelled on Liandi, Richard H's concept and The Tennessee SelfConcept Scale. The data were then analyzed by Partial Least Squares (PLS) to test the hypothesis and form the empirical model.

Results: The results showed social care was able to improve the self-concept of leprosy patients $(\mathrm{T}=5.800, \mathrm{~T}>1.96)$.

Conclusion: Therefore, it is expected that nurses continuously synergize in maintaining social care conditions with the community in order to improve the self-concept of leprosy patients.

\section{ARTICLE HISTORY}

Received: September 7, 2018

Accepted: April 21, 2020

\section{KEYWORDS}

leprosy patients; self-concept; social care

\section{CONTACT}

Nur Hamim

$₫$ hnurhamim@gmail.com

$\equiv$ Nursing Study Program of Hafzhawaty Zainul Hasan

Probolinggo

Cite this as: Hamim, N., Mariani, M., \& Sismulyanto, S. (2020). Social Care in Improving Self-Concept of Leprosy Patients. Jurnal Ners, 15(1), 37-41. doi:http://dx.doi.org/10.20473/in.v15i1.6746

\section{INTRODUCTION}

Infectious diseases are common in developing countries with low socioeconomic conditions. One such is leprosy (Montaya, 2010). Leprosy is common in developing countries as a result of the country's limited ability to provide adequate services in the areas of health, education, and socioeconomic welfare in the community; leprosy is still feared by the community, among families, and even including some health workers (Lucinda, 2014). The World Health Organization (WHO) (2013) indicates that Indonesia has 17,012 cases of leprosy, although its leprosy prevention is better, as indicated by being ranked 4th after India, Brazil and Nepal. As of December 2015, in the preceding ten years, Indonesia succeeded in reducing leprosy morbidity by $85 \%$ from 107,271 people to 17,012 people (WHO, 2013). From these data, East Java is the province with the most leprosy patients, with the number of patients reaching 4,293 cases, with patients who have a lifelong disability as many as 184 and, childhood sufferers as many as 117 in the region of Madura, Tapal Kuda and Pantura (Ministry Of Helath (MOH), 2015). The case of leprosy patients in Probolinggo regency ranks seventh after Tuban, while the first order is Sampang Regency (Ministry Of Helath (MOH), 2015). Leprosy patients will experience body image or present their individual self-image. Illness and serious injury can damage self-concept, including disability. Adapting the behavior of illness can affect a person's feelings about their identity (Hobfolf, 2006). Threats to body image as well as self-esteem are often accompanied by feelings of shame, inadequacy and guilt. In a healthcare setting, people sometimes have to adjust to a situation that threatens their self-esteem, (Hasselhorn, 2010) and leprosy patients will experience some problems, both physically, psychologically, socially, and economically (Misch, 2010). A preliminary survey conducted in February 2016 from medical records at Glagah Puskesmas 
Table.1 Respondents' Characteristics of Leprosy Patients in Probolinggo District.

\begin{tabular}{|c|c|c|}
\hline Variable & $\mathbf{n}$ & $(\%)$ \\
\hline \multicolumn{3}{|l|}{ Gender } \\
\hline Male & 32 & 57 \\
\hline Female & 24 & 43 \\
\hline \multicolumn{3}{|l|}{ Age (years old) } \\
\hline $20-30$ & 11 & 20 \\
\hline $31-40$ & 18 & 32 \\
\hline$>40$ & 27 & 48 \\
\hline \multicolumn{3}{|l|}{ Marital status } \\
\hline Married & 35 & 62 \\
\hline Not Married & 21 & 38 \\
\hline \multicolumn{3}{|l|}{ Duration of suffering (years) } \\
\hline $1-5$ & 24 & 43 \\
\hline $6-10$ & 19 & 34 \\
\hline$>10$ & 13 & 23 \\
\hline
\end{tabular}

Table. 2 Family Support to Leprosy Patients in Probolinggo District.

\begin{tabular}{|c|c|c|c|c|c|c|c|c|c|}
\hline \multirow{3}{*}{ No } & \multirow{3}{*}{ Family Support } & \multicolumn{8}{|c|}{ Category } \\
\hline & & \multicolumn{2}{|c|}{ Good } & \multicolumn{2}{|c|}{ Enough } & \multicolumn{2}{|c|}{ Low } & \multicolumn{2}{|c|}{ Total } \\
\hline & & $\mathbf{n}$ & $\%$ & n & $\%$ & $\mathbf{n}$ & $\%$ & n & $\%$ \\
\hline 1 & Empathy & 6 & 10 & 25 & 45 & 25 & 45 & 56 & 100 \\
\hline 2 & Encouragement & 6 & 10 & 25 & 45 & 25 & 45 & 56 & 100 \\
\hline 3 & Facilitative & 7 & 12 & 24 & 43 & 25 & 45 & 56 & 100 \\
\hline 4 & Participatory & 9 & 16 & 23 & 41 & 24 & 43 & 56 & 100 \\
\hline
\end{tabular}

Table. 3 Social Care of Leprosy Patients in Probolinggo District

\begin{tabular}{|c|c|c|c|c|c|c|c|c|}
\hline \multirow{3}{*}{ Social Care } & \multicolumn{8}{|c|}{ Category } \\
\hline & \multicolumn{2}{|c|}{ Good } & \multicolumn{2}{|c|}{ Enough } & \multicolumn{2}{|c|}{ Low } & \multicolumn{2}{|c|}{ Total } \\
\hline & $\mathbf{n}$ & $\%$ & $\mathbf{n}$ & $\%$ & $\mathbf{n}$ & $\%$ & $\mathbf{n}$ & $\%$ \\
\hline Opportunity & 6 & 10 & 25 & 45 & 25 & 45 & 56 & 100 \\
\hline Freedom & 6 & 10 & 25 & 45 & 25 & 45 & 56 & 100 \\
\hline Attention & 7 & 12 & 24 & 43 & 25 & 45 & 56 & 100 \\
\hline
\end{tabular}

Table 4. Self-Concept in Leprosy Patients in Probolinggo District

\begin{tabular}{|c|c|c|c|c|c|c|c|c|}
\hline \multirow{3}{*}{ Self-Concept } & \multicolumn{8}{|c|}{ Category } \\
\hline & \multicolumn{2}{|c|}{ High } & \multicolumn{2}{|c|}{ Medium } & \multicolumn{2}{|c|}{ Low } & \multicolumn{2}{|c|}{ Total } \\
\hline & $\mathbf{n}$ & $\%$ & $\mathbf{n}$ & $\%$ & $\mathbf{n}$ & $\%$ & $\mathbf{n}$ & $\%$ \\
\hline Self-image & 6 & 10 & 25 & 45 & 25 & 45 & 56 & 100 \\
\hline Self-esteem & 7 & 12 & 24 & 43 & 25 & 45 & 56 & 100 \\
\hline Role & 9 & 16 & 23 & 41 & 24 & 43 & 56 & 100 \\
\hline
\end{tabular}

Probolinggo District showed that there were 34 patients recorded from 2012 to 2015 and that most of the patients $(41.03 \%)$ had experienced disability of Busier Pausi (PB), while those with disability level of Multi Basiler (MB) was as much as $58.97 \%$. From the results of field observations with the help of health cadres from Glagah Puskesmas, researchers found that leprosy patients feel their self-esteem (selfconcept) is very low. Patients isolate themselves from society, even families. The main goal is for patients to socialize to the community to improve their selfconcept through s social approach. Social care in the provision of health services needs to be done (Curtis, van der Heijden,Kümmerlin, van Dam, \& van der Schoot, 2009) so that,hopefully, the family is not just resigned to the state of patients who also isolate themselves from the family.Thus the nurse must also attend the family and patient to provide health education. The purpose of this research is to formulate a social care model in improving the selfconcept of leprosy patients.

\section{MATERIALS AND METHODS}

This research used explanatory research survey method with a cross-sectional approch. The sample was 56 respondents. The variables in this study were family support, social care and self-concept. The data were collected by three kinds of instruments. The family support was measured by questionnaireadopted from Liandi (2011). The social care using questionnaires whas developed by researchers based on Richard H's concept (2015). The Tennessee Self-Concept Scale (Fitts, 1965) was used for measuring self-concept. The analysis technique used is a model based on variance or componentbased, known as Partial Least Squares (PLS). PLS is a powerful analysis, since it does not assume that data should be of a certain scale, can work with a small sample, and can also be used to confirm the theory (Ghozali, 2009). This study was approved by the Hafshawaty Pesantren Zainul Hasan Institute of 
Table 5. Values of Outer Weights in Outer Model of Self-Concept of Leprosy Patients

\begin{tabular}{lcccccc}
\hline \multicolumn{1}{c}{ Variable } & $\begin{array}{c}\text { Original } \\
\text { sample } \\
(\mathbf{O})\end{array}$ & $\begin{array}{c}\text { Sample } \\
\text { mean } \\
(\boldsymbol{M})\end{array}$ & $\begin{array}{c}\text { Standard } \\
\text { Deviation } \\
(\text { STDEV) }\end{array}$ & T statistic & P value & Information \\
\hline Empathy & 0.999 & 0.897 & 0.115 & 8.697 & 0.000 & Significant \\
Encouragement & 0.086 & 0.085 & 0.294 & 0.295 & 0.769 & Not significant \\
Facilitative & -0.164 & -0.162 & 0.206 & 0.799 & 0.425 & Not significant \\
Opportunity & 0.519 & 0.520 & 0.108 & 4.800 & 0.000 & Significant \\
Freedom & 0.323 & 0.299 & 0.101 & 3.205 & 0.001 & Significant \\
Attention & 0.338 & 0.338 & 0.095 & 3.572 & 0.000 & Significant \\
Participation & 0.371 & 0.361 & 0.094 & 3.937 & 0.000 & Significant \\
Self-image & 0.416 & 0.406 & 0.079 & 5.238 & 0.000 & Significant \\
Self-esteem & 0.293 & 0.277 & 0.068 & 4.312 & 0.000 & Significant \\
Self-role & -0.090 & -0.083 & 0.093 & 0.964 & 0.336 & Not significant \\
Personal Identity & 0.542 & 0.518 & 0.076 & 7.108 & 0.000 & Significant \\
Self-ideal & 0.136 & 0.120 & 0.122 & 1.115 & 0.266 & Not significant \\
\hline
\end{tabular}

Table 6. T-Statistic Value on Inner Model of Self- Concept of Leprosy Patients

\begin{tabular}{|c|c|c|c|c|c|c|}
\hline $\begin{array}{l}\text { Direct and Indirect Causality } \\
\text { Relationships between exogenous } \\
\text { and endogenous variables }\end{array}$ & $\begin{array}{c}\text { Path } \\
\text { parameter } \\
\text { coefficient }\end{array}$ & $\begin{array}{l}\text { Sample } \\
\text { Mean } \\
\text { (M) }\end{array}$ & $\begin{array}{c}\text { Standard } \\
\text { Dev }\end{array}$ & $\begin{array}{c}T- \\
\text { Statistic }\end{array}$ & $\begin{array}{c}P \\
\text { value }\end{array}$ & Information \\
\hline $\begin{array}{l}\text { The influence of Family Support (X1) } \\
\text { on self-concept (Y1) }\end{array}$ & 0.448 & 0.447 & 0.091 & 4.953 & 0.000 & Significant \\
\hline $\begin{array}{l}\text { The influence of Family Support (X1) } \\
\text { on Social care (X2) }\end{array}$ & 0.344 & 0.393 & 0.087 & 3.960 & 0.000 & Significant \\
\hline $\begin{array}{l}\text { The influence of Social care (X2) on } \\
\text { Self-concept (Y1) }\end{array}$ & 0.549 & 0.536 & 0.087 & 6.285 & 0.000 & Significant \\
\hline
\end{tabular}

variables. Indicator of self-concept variable (self-role and self-ideal) was not significant ( $\mathrm{p}$ value $>0.05$ ), so the indicator must be discarded and only self- image, self-esteem and personal identity were significant and maintained in the model.

\section{Inner model test result}

Table 6 explains the path coefficient of paramaters based on PLS test. Individual reflective size is said to be valid if it has a loading correlation loading with the latent variable construct measured, $\geq 5 \%$, or the $\mathrm{T}$ statistic value must be greater than 1,96 (two-party test) at the significance level $\alpha=5 \%$. Table 6 shows that family support influences the self-concept of leprosy patients $(\mathrm{T}=4.953)$, family support affects social care $(\mathrm{T}=3.960)$, and social care influences the self-concept of leprosy patients $(\mathrm{T}=6.285)$.

The self-concept model of leprosy patients is composed of three variables: family support, social care and self-concept. Self-concept in leprosy patients is directly affected by family support and social care. Self-care conditions of leprosy patients can be reinforced indirectly through social care channels reinforced by family support (Hamim, 2015). Based on the outer weights of the outer model test, there are several indicators of each latent variable that are not significant, so it must be reconstructed first to obtain the ideal model.

Based on Table 7, the results of the reconstruction of the leprosy self-concept model developed from
However, further research is needed, in particular longitudinal and experimental design, to determine the effectiveness of social support on self-care behavior in individuals with heart failure, as this review reveals most of the cross-sectional, correlational research limits the ability to infer causality (Lucinda, 2014).

Thus, the important role of family support is to change the mindset of lepers and other people to bring about the quality of a better work life. These conditions will cause the desire of the patient to socialize with the surrounding environment and includes activities that exist within each household, . This is directed to improve working life conditions, which can raise the spirit of the sufferers in carrying out the task of achieving a normal life. Similarly, people around the patient will feel an integral part of their everyday life.

\section{The influence of family support on social care}

The condition of the influence of family support on social care has T-statistics of 3.977 ( $\mathrm{T}>1.96)$. Thus, there is influence of family support to social care. The condition of good support will have an impact on good culture so that the patient's activity can be improved maximally; the nurse will also benefit from the positive activity. Therefore, all components in the society are expected to maintain the existing conditions so that society will continue to be part of 


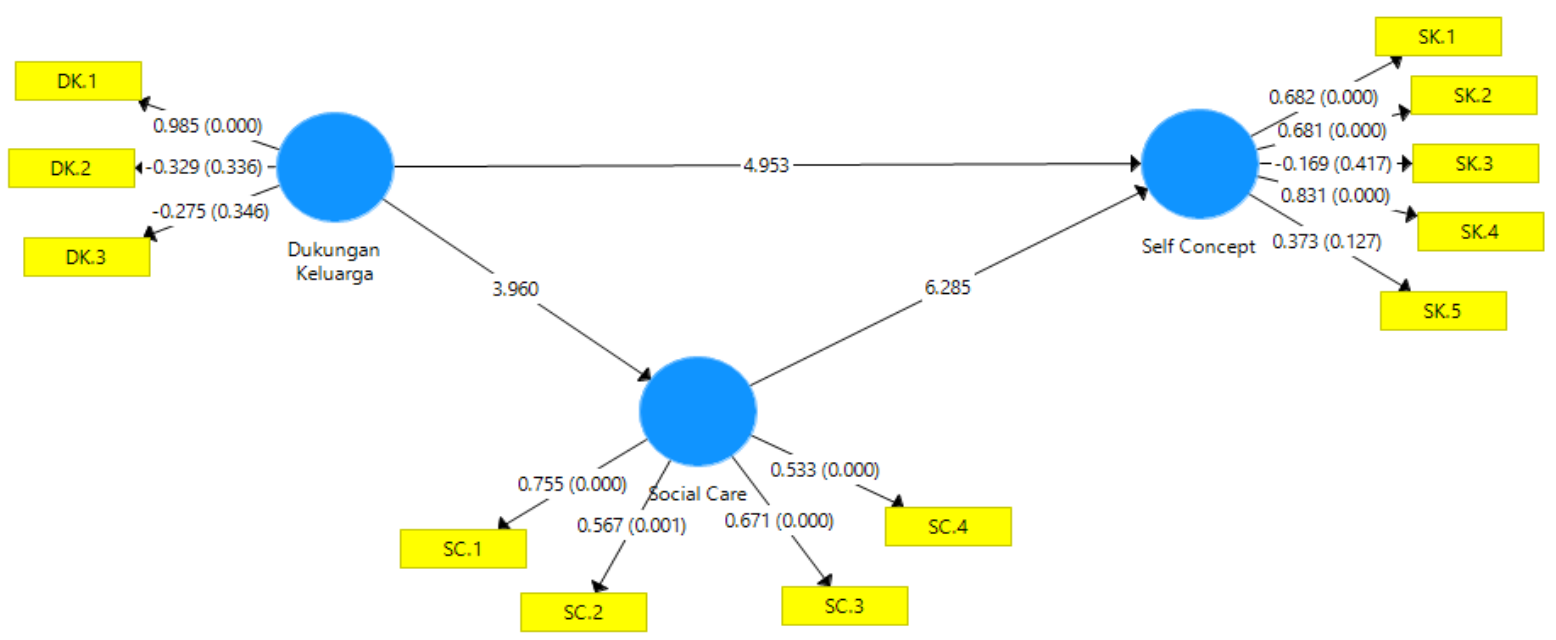

Figure 1. Self-concept model of leprosy patients based on path analysis before reconstruction

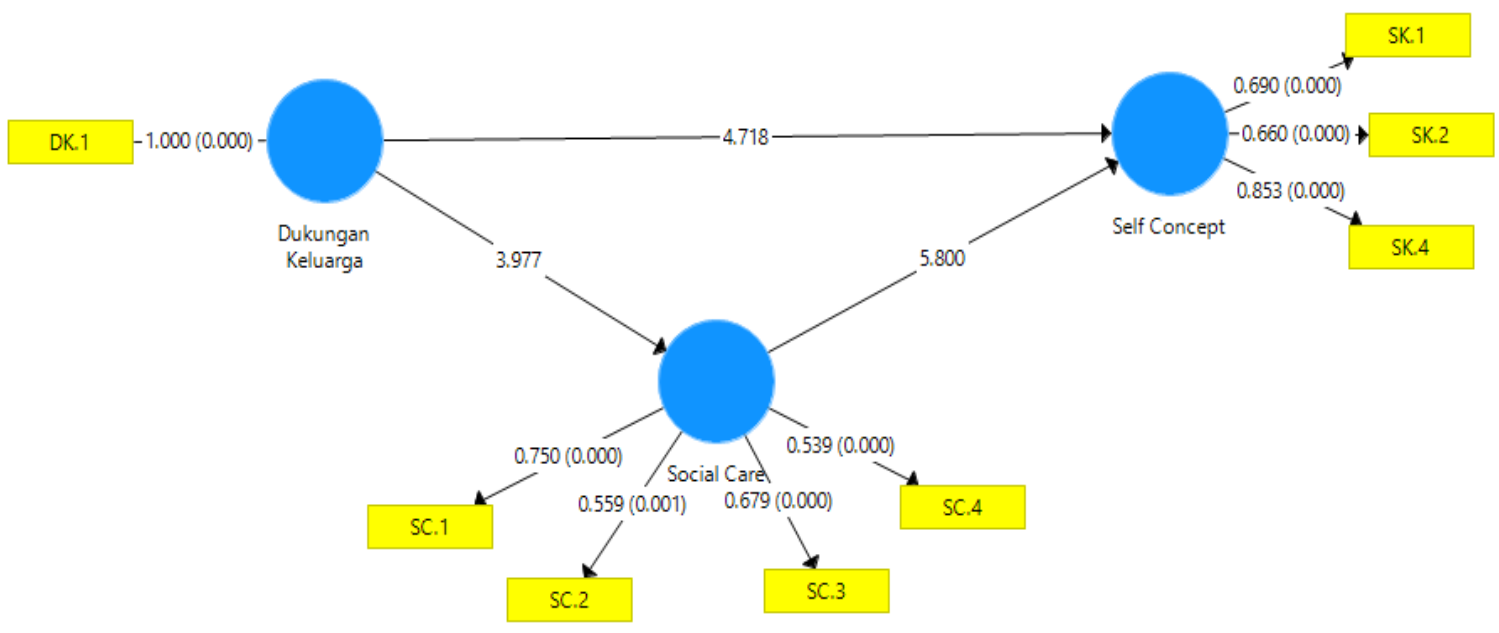

Figure 2. Test result model after reconstruction

the initial conditions expected by the patient (Friedman, 2013).

Social services are divided into two groups. First is social services, which are very complicated and comprehensive and so difficult to determine identity (Curtis et al., 2009). These services include education, social assistance in the form of money by the government, medical care and public housing. The second is clear social service scope and its services, although these are always changing. This service can stand on its own, for example child welfare and family welfare, but it can also be a part of other institutions, such as social work in schools, medical social work, social work in public housing and social work in industry. Social service in the broad sense is any service intended to improve the social welfare of human, while, in the narrow sense, it is the service given to some people who are less fortunate (Desi, 2011). Thus, in a synergy,the better the support of the family will have an impact on the overall social attention, because how can social attention can be maximized if there is no support from the family on the patient.

\section{The effect of social care on the self-concept of leprosy patients}

The results showed the influence of social care on the self-concept of leprosy patients. Table shows the influence of social care on self-concept of leprosy patients with a T-statistics score of 5.800 ( $\mathrm{T}>1.96)$. There is influence of social care to self-concept of leprosy patients. The concept of self defines all ideas, thoughts, feelings, and beliefs that involve individual knowledge about self and affects the relationship with others (Stuart \& Sundeen, 2006). Self-concept consists of self-image, self-esteem, role of self, selfidentity and self-ideal, while the factor that influences the formation and development of self-concept is age. Self-concept is formed along with increasing age whereby this difference is more related to development tasks. Education also influences selfconcept. A person with a high level of education improves his achievement. If his achievement increases, then his self-concept will change. Socioeconomic status affects the acceptance of others toward him. Family relationships of a person 
Table 7. T-Statistic Value of Inner Model Self- Concept of Leprosy Patients After Reconstruction

\begin{tabular}{lcccccc}
\hline $\begin{array}{c}\text { Direct and Indirect Causality } \\
\text { Relationships between exogenous } \\
\text { and endogenous variables }\end{array}$ & $\begin{array}{c}\text { Path } \\
\text { parameter } \\
\text { coefficient }\end{array}$ & $\begin{array}{c}\text { Sample } \\
\text { Mean }\end{array}$ & $\begin{array}{c}\text { Standard } \\
\text { Dev }\end{array}$ & $\begin{array}{c}\text { T- } \\
\text { Statistic }\end{array}$ & $\begin{array}{c}\boldsymbol{P} \\
\text { value }\end{array}$ & Information \\
\hline $\begin{array}{l}\text { The influence of Family Support (X1) on } \\
\text { Self - Concept (Y1) }\end{array}$ & 0.441 & 0.433 & 0.093 & 4.718 & 0.000 & Significant \\
$\begin{array}{l}\text { The influence of Family Support (X1) on } \\
\text { Social Care (X2) }\end{array}$ & 0.344 & 0.363 & 0.086 & 3.977 & 0.000 & Significant \\
$\begin{array}{l}\text { The influence of Social Care (X2) on Self- } \\
\text { Concept (Y1) }\end{array}$ & 0.556 & 0.563 & 0.096 & 5.800 & 0.000 & Significant \\
\hline
\end{tabular}

who has a close relationship with his or her family members will identify with others and want to develop the same personality pattern, if this is a same-sex character it will develop a self-concept worthy of his sex. Other people make us know ourselves by knowing others first. How another knows ourself will contribute to form self-concept. Individuals are accepted by others, respected and liked because of their condition and individuals will tend to be respectful and accept him. Conversely, when others always underestimate themselves, blame, and reject, they will tend to not like him.

\section{CONCLUSION}

There is influence of family support to the self concept of leprosy patients. The findings show the influence of family support on the self-concept of leprosy patients. The better the family support, the higher the self-concept of leprosy patients. There is influence of family support to social care. From the results of analysis, it shows the influence of family support to social care, The better the family support, the better the social attention of society to leprosy patients.There is influence of social care to selfconcept of leprosy patients. Results analysis shows an influence of social care on self-concept of leprosy patients; the better social care or social attention of people to leprosy patients, the higher the self-concept of leprosy patients.

\section{REFERENCES}

Chin, W. W. (1998). The Partial Least Squares Aproach to Structural Equation Modeling. Modern Methods for Business Research.

Curtis, L. B. van der Heijden A. Kümmerling K. van Dam, E. van der Schoot, M. E.-B. (2009). Unit cost of Health and Social Care, University of Kent Canterbury.

Desi, R. . (2011). Dukungan Psikososial Keluarga Penderita Kusta di Kabupaten Pekalongan. Jurnal.Unimus.Ac.Id.

Friedman. (2013). Keperawatan Keluarga: Teori, dan
Praktek. Edisi 3. Jakarta: EGC.

Ghozali, I. (2009). Model Persamaan Struktural Konsep dan Aplikasi denganProgram AMOS Vers 5.0. Semarang: Badan Penerbit-UNDIP.

Hamim, N. (2015). Caring Behaviors Nurse based on Quality of Nursing Work Life and Self-Concept in Nursing Nurses in Hospital. International Journal of Development Research October 2015, 5 (10), 5803-5808.

Hasselhorn, H. M. (2010). The Impact of Social Support Upon Intention to Leave among Female Nurses in Europe: Secondary Analysis of Data from the NEXT survey. International Journal of Nursing Studies, 4(47), 434-445.

Hobfolf, S. E., London, P. (2006). The Relationship of Self-Concept and Social Support to Emotional Distress among Women during War. Journal of Social and Clinical Psychology 4.2, June 2006, 4.2, 189-203.

https://doi.org/https://doi.org/10.1016/j.womb i.2013.09.004

Lucinda, J. G., \& J. S. G. (2014). Social Support and SelfCare Behaviors in Individuals with Heart Failure: An Integrative Review. IInternational Journal of Nursing Studies International Journal of Nursing Studies February 2014, 51(2), 320-333.

Ministry Of Helath (MOH), R. (2015). Buku Pedoman Nasional Pengendalian Penyakit Penyakit Kusta.Direktorat Jendral Pengendalian Penyakit dan PenyehatanLingkungan Departemen Kesehatan RI.

Misch, E. A. (2010). Microbiol. Mol. Biol. Rev. Journal American Society for Microbiology (ASM), 74(589620).

Montaya D. (2010). Learning from leprosy : insight into the human innate immune response. Advance in Immunology, 105, 1-24.

Stuart \& Sundeen. (2006). Buku Saku Keperawatan. Edisi3.Jakarta : $E G C$.

WHO. (2013). Seventh Expert Committee.Leprosy Elimination.Retrieved May 4, 2013, from http://www.who.int/lep/resources/expert/en/ind ex2.html. 